\title{
Understanding migration in a globalized era: How postcolonialism views diaspora
}

\author{
Asri Saraswati ${ }^{\mathrm{a}, 1^{*}}$ \\ a Universitas Indonesia, Jalan Prof. Dr. Selo Soemardjan, Depok, 16424, Indonesia \\ 1 asri-s@ui.ac.id
}

Sejarah Artikel:

Diterima: 29 April 2021

Direvisi: 5 September 2021

Disetujui: 14 September 2021

Tersedia Daring: 31 Oktober 2021

Kata Kunci:

Diaspora

Pergeseran Epistemologi

Pascakolonialisme

\section{INFO ARTIKEL} \begin{abstract}
ABSTRAK
Artikel ini adalah sebuah pembacaan kritis terhadap pendekatan poskolonial, mulai dari pemikir utama dalam teori kritis hingga pemikiran yang lebih baru, yang selama ini membantu kajian sastra dan budaya dalam memahami konsep diaspora. Diaspora merujuk pada mobilitas manusia yang terjadi akibat penjajahan dan globalisasi serta karya sastra yang dihasilkan melalui pergerakan manusia tersebut. Tujuan artikel ini adalah untuk memahami perkembangan pendekatan poskolonial dalam memahami pengalaman hidup migran dan konsep diaspora. Metode yang diterapkan adalah analisis teks dengan menyajikan kajian literatur ekstensif mengenai studi pascakolonial. Artikel ini mengidentifikasi perspektif intelektual kajian pascakolonial dalam menggunakan istilah diaspora untuk mencermati bagaimana bidang studi ini meredefinisi istilah tersebut untuk mengkaji migrasi di era modern, yang dapat bersifat sukarela maupun tidak sukarela, serta permanen ataupun sementara. Artikel ini berargumen bahwa istilah diaspora terus-menerus mengalami kontestasi dan dijadikan relevan dengan konteks masa kini sehingga memberikan peluang bagi masyarakat Global South, termasuk Indonesia, untuk mencermati agensi mereka dalam pengalaman hidupnya sebagai migran dan warganegara dunia yang berpindah-pindah.
\end{abstract}

Keywords:

Diaspora ABSTRACT

Epistemological Shift

This article is a critical reading on postcolonial scholarship, ranging from tenets in the field to more current theories, that has allowed literary and cultural studies scholars to understand the term diaspora. Diaspora refers to the various mobilities caused by colonization and globalization, and the literature produced through people's movement across borders. This article aims to reflect on the development of postcolonial studies on how this field of study has come to address the migrant's lived experience and conceptualize the term diaspora. The method applied by this article is literary analysis, as the paper provides an extensive literature review of scholarships in postcolonial studies. By doing so, the article identifies the ways in which postcolonialism has engaged with the term diaspora and is working to reconfigure the term to address modern era migration, that can be both voluntary and involuntary, as well as permanent and temporary. The article ruminates on how diaspora continues to be a contested term and is made relevant to current context, providing ways for communities of the Global South, including Indonesia, to seek agency in their experience as migrants and global mobile citizens.

(C) 2021, Asri Saraswati This is an open access article under CC-BY-SA license (c) (1) ()

How to Cite: Saraswati, A. (2021). Understanding migration in a globalized era: How postcolonialism views diaspora. Satwika: Kajian Ilmu Budaya dan Perubahan Sosial, 5 (2), 353-369, https://doi.org/10.22219/satwika.v5i2.16432 


\section{Introduction}

In July 2012, in Los Angeles, United States, more than 2000 Indonesians gathered to attend the first congress of Indonesian Diaspora Network (IDN), an independent and non-profit organization of Indonesians living outside their homeland. The event was opened by President Susilo Bambang Yudhoyono and included a Lifetime Achievement Award presented to the third Indonesian president, B.J. Habibie, a wellknown intellectual who had also spent time abroad. Today, the IDN consists of 60 chapters connecting Indonesians in various parts of the world. Their congresses are not only communal gatherings where Indonesians abroad can be in touch with cultures of the homeland, but they also include panels that target various formal issues, such as the economic and social contribution of Indonesians abroad as well as advocating for dual citizenship. Members of the IDN include communities who helped pass Law Number 12 Year 2006, with specific passages in Articles 4 and 5, making it possible for Indonesians to have dual citizenship until age 18. The articles advocated by IDN members have formalized dual citizenship for foreign-born Indonesians until they are at an age that can make an informed decision about the citizenship they would like to choose. The IDN brings a spotlight to the complex issue of citizenship and helps highlight the emotional ties that Indonesians abroad have towards their homeland, thus breaking the dominant discourse of the 'brain drain' and Indonesian living abroad as unpatriotic opportunists (See Latifa \& Beta, 2019). A scholarly jargon in postcolonial studies, 'diaspora' is used in IDN's name to serve as an entryway to address issues significant to the lives of migrants and communicate the political and economic connection they continue to have with their home country.

The term 'diaspora' derives from Greek the word 'dia speiro', which means 'to sow' and 'to spread' and was traditionally used to refer to the Jewish people's exodus as told in Christian biblical texts (Cohen, 2008; Murray, 2014). However, the collective community created by Indonesian communities abroad through IDN illustrates a renewed interest and a different engagement with the term 'diaspora' in this modern time. Today, peoples and communities move across borders not only as displaced societies who are forcefully removed by warfare but also as the impact of globalization, following the mobility of capital. Globalization creates connection and interdependence between nations and peoples across borders, making it possible for commodities from developed countries to enter the developing nations and multinational companies and organizations from the so-called western countries to enter nations in Asia and Africa (Gabriel, 2015). The flow of capital makes way for the flow of people. This context requires us to reify and redefine the term diaspora.

Robin Cohen categorizes diaspora based on historical, social, economic, and religious specificities. He conjures five types of diaspora: victim, labor, trade, imperial, and cultural diasporas (Cohen, 2008). Cohen's taxonomy allows us to recognize intersections between categories. British diaspora, for instance, moved due to their Calvinist beliefs, but they also colonized the land they arrived at, thus revealing how trade and imperialism intersected. Drawing back from the age of the Ottoman Empire to the current dynamics of global migrants, Cohen assesses the experiences of Chinese, Lebanese, Jewish, African, Armenian, Caribbean, Indian, and British diaspora against the diasporic taxonomy. $\mathrm{He}$ scrutinizes the different state powers that communities face to provide a general broad map of people's migration and establish that the world is created through the migration of people on the one hand and the state control that causes their displacement on the other.

For Indonesians, migration can be recognized in waves, catalyzed by national 
crises, nation-state economic agendas, and the increased chance to study and work abroad. One of the prominent reasons for Indonesians to move abroad was to seek security, specifically during Cold War turmoil that resulted into the targeting of alleged communist party sympathizers during 1960s to 1970s, and 1998 riots when protests against the authoritarian president Soeharto erupted into violence against religious and ethnic minorities (Kitamura; Vickers, 2005; Widjanarko, 2007). In recent decades, Indonesians have also become increasingly mobile with the rise of global capitalism that causes demand for working professionals and the brokering of lowskilled labor and domestic workers by private entities. At the same time, the country has witnessed an internationalization of higher educational in the last decade and the increased number of government-sponsored scholarships, which causes an upsurge in the number of young people seeking education abroad that often leads to employment outside of the country. This migration pattern allows individuals to cease settling in one space, and elites with capital and privilege can circumvent restrictive citizenship policies, maneuver border regulations, and practice a form of "flexible citizenship" (Ong, 1999). We also observe different experiences of migration, one that is voluntary rather than involuntary, and less permanent than the conventional notion of 'immigrant', but nonetheless challenging and a form of struggle in their own right.

Regardless of the nature and purpose of the migration, diaspora communities occupy a precarious position as they face changing immigration policies established by the nation-state (Budianta, 2015) as well as the struggle to adapt and built subjectivity and identity amidst cultures, often facing pressure to assimilate to the culture of the host country. Issues of the modern-day diaspora can be observed in various forms of travel writing and migrant literature. Many of these narratives are significantly different from refugee literature about communities dislocated by global conflict who are deprived of their homeland and forced to live in-between spaces of the so-called East and West. Efforts to extend the term diaspora to include the experience of the global migrants who are temporary and voluntary in their movement across borders are often stifled by the dominant notion of diaspora as displaced and deprived ethnic groups, moving in a oneway trip from the so-called East to West. The book Asian Diaspora: New Formations, New Conceptions (Parreñas \& Siu, 2007), for instance, works to uncover new contexts and subjects that are previously uncaptured in the concept 'diaspora'. Writers of the book counter essentialist and universalistic understanding of 'migrant' and 'diaspora' by unearthing the case of Korean adoptee, Trinidad Indian, the Korean proindependence movement in the U.S., as well as noting the variety of spaces other than homeland and host country to which diaspora communities are attached. Moving beyond the simplistic route between East and West, the book includes a chapter that discusses British-raised Indians who continued family business of providing spices for Indian descents in Guyana, showing the networks of Indian diaspora across nation state. Their connections are maintained through nostalgia of tastes of the homeland as well as trade and capital.

While offering multiple study cases and various forms of diaspora's connections to the homeland, Asian Diaspora sets a definition for diaspora by noting three conditions of a diasporic community:

"(1) displacement from the homeland under the nexus of an unequal global political and economic system; (2) [...] alienation and the maintenance of affiliation to both country of residence and the homeland; (3) [...] collective consciousness and connectivity with other people displaced from the homeland across the diasporic terrain" (Parreñas \& Siu, 2007).

This definition of diaspora illustrates how alienation, marginality, and collective 
consciousness remain as prime characteristics of diaspora even when scholars attempt to challenge conventional understanding of the term. The phenomenon of temporary migrations of international students and elites who may or may not choose to gather with communities who share the same homeland would not be fitting to this definition of diaspora. This suggests the limits in the definition of diaspora in postcolonial studies even when the field seeks to contest and reify the term. Scholars also warn how the misuse of the term can lead to the undermining of the diasporic experience of refugees and displaced migrants, as Dodson writes, " $[\mathrm{M}]$ isuse of such a universal term risks diminishing a collective understanding of our world" (Dodson, 2016). Postcolonialism, therefore, is facing an interesting point in its development as a field, in which it seeks to understand global migration, the use and misuse of diaspora as a term and explores new ways to address modern-day migration that includes the violent annexation of a community's land, the displacement of peoples due to modern warfare, as well as work migration and other motives and patterns of migration.

Moving away from the term 'diaspora', scholars have also engaged with "newer" frameworks such as 'cosmopolitanism' and 'transnationalism' to understand modern-day migration and interactions between peoples that transgress geographical borders. Interestingly, as new concepts emerge, nonwestern scholars and communities in Asia are working to reify the term 'diaspora' and apply it as an agency strategy, as illustrated by the Indonesian Diaspora Network. As such, I see the urgency to revisit the term 'diaspora' to understand how the field has established the term, working to contest and redefine it to address modern-day migration. This paper traces the ways in which postcolonialism has laid important groundwork in theorizing diaspora and reveals new possibilities to engage with diaspora and narratives about the modernday migrants. The paper's objective is twofold. First, it aims to understand how colonial relations have created power structures between the colonized and the empire, between the 'East' and the 'West', and how this framework has been used to understand the dislocations of the colonized. Through this perspective, postcolonial studies shed light on the agency of the colonized and the diaspora and their effort to 'write back' against the colonizer (Ashcroft, Griffiths, \& Tiffin, 2002; Hall, 2002). Secondly, this paper follows postcolonialism as a field of study that grows along with its effort to understand migration in the global age that is beyond, yet still influenced by, power structures created by colonialism. As such, this paper is driven by the following question: How has postcolonialism depicted the migrant issue from the early days of "the empires writes back" to narratives of global migrants driven and controlled by new power structures? A more practical purpose of this article is to re-introduce key writings in postcolonial studies that have helped conceptualize and offer methodologies to understand diaspora communities and diaspora narratives critically. By doing so, this essay maps out important scholarships in the field and understands how various humanities fields cross paths as they provide approaches and insights to the immigrant's experience.

The body of this essay consists of four parts. I begin with Edward Said and his book Orientalism (Said, 1979), laying the foundation in postcolonial thinking. The first part of this article elaborates the book's significant contribution and the questions it leaves behind. The second part discusses the work of cultural studies scholar Stuart Hall's work on diaspora identity and his influence on postcolonial studies scholarship. While Said and Hall's works are not recent, I see the importance of revisiting them as tenets in the field which have made way for current scholarships on global diaspora, thereby revealing how the field currently re-engages with the issue. Lastly, the third and fourth parts of the paper look into works by Ien Ang and Robin Cohen on diaspora and global 
migrants. Ultimately, this article reveals the development of postcolonial studies as the field in its effort to understand global migration as implications of state power and comprehend the diaspora's position and agency as well as the construction of selfhood that is hybrid and versatile.

This article argues that the term 'diaspora' remains a contested term, with which Asian scholars engage better to understand the mobility of communities of the Global South. More importantly, through observing the ways in which postcolonialism strives to capture the term diaspora and scrutinize power dynamics brought by global migration, this article reveals the field's versatility and its critical lens in viewing the scope of state and global power by seeking meeting points with other fields in the humanities.

\section{Method}

This paper is an extensive literature review that critically reads key scholarships in postcolonialism, viewing them in conversation with writings and thoughts in other fields in the humanities. As its research method, this article conducts a close reading of sources and theories, observing them in their intersection with postmodern philosophy, global studies, and ethnic studies. For instance, Hall's work will be viewed in reference to other scholars such as Homi Bhabha, Louis Althusser, and Michel Foucault, while Cohen and Ang's works will be viewed in conversation to culture studies, ethnic studies, and postcolonial scholarships.

\section{Result and Discussion}

\subsection{Pathways Established by Orientalism}

Edward Said's Orientalism is often lauded as the book that creates the groundwork for postcolonial studies. In his work, Said unearths various orientalist narratives through which western imperialism controlled the colonized East (Said, 1979). Said argues that Orientalists, western intellectuals of various fields in the 18 th century that dedicated themselves to study the Near East, had long performed cultural hegemony by depicting the Near East as "primitive", and their narratives help justify western imperialism over the eastern hemisphere. The book reveals how Orientalism disguises itself as a scientific field while disseminating a propagandist view of the East, and Islam in particular, as "less than" the West. Said's approach resonates with Gramscian concept of hegemony, Foucault's notion of institutionalized power, and Raymond William's concept of the politics of culture and literature. Orientalism reveals how power is exercised through science and educational institutions in their production of knowledge. As the work details how racial biases are reinforced by scholarly texts to justify colonization further as well as to control people of color and non-western nations, Said helps establish postcolonialism, an approach and critical theory dedicated to examining the impact of western colonialism in the world and the hegemonic system that maintains western imperialism.

One of the valuable contributions of Orientalism is its method of shedding light on the link between the discursive and material conditions. Said reveals the misrepresentation of the East is not just 'imaginary', but it is damaging as it brings real material changes to the landscape and the conditions of the East. He discusses the connection between 'the imagined' and 'the material' rigorously and provides illustrations on how perspectives about the Orient shift as the material world changes. Napoleon's power over Egypt and the Suez Canal helped shift European's perspective of the East as suddenly appearing "closer". Furthermore, the construction of the Suez Canal was rooted in the inspiration to build something "new" in the "old world" Egypt, a notion that is deeply rooted in the stereotyping of Orient as "backward", "empty", and "incapable of progress".

By showing the implication of discursive notions to real material conditions, Said shows that repression toward the Orient cannot be undone by merely eliminating the 
derogatory images of the East. Further showing the connection between the imaginary and its material reality, Said warns that the Orient is in danger of internalizing the orientalist images. For Indonesians, this orientalist image is depicted in the term 'inlander', a moniker used by Dutch colonials to refer to the 'indigenous' in the East Indies. The word 'inlander' bears meaning as being "lazy" and "backward", thus serves as a tool of Other-ing that construct the image of Indonesians as unable to self-govern (Gouda, 1993). The term can create ambivalent attitudes toward (white) foreigners as well as the feeling of subordination, which has been recognized as one of the transgenerational impacts of colonialism. This leads to the second critical contribution of Said's work, in which he reveals the role of narration to establish and sustain colonial relations as the so-called East is deemed unable to self-govern, thereby justifying colonization by the western nations. This discourse operates by establishing dichotomies of colonized/colonizer, native/western, civilization/culture, in which the so-called East is equated to "savage" and "primitive".

Through his work, Said calls out scholars and academics to be aware of their subjectivity and position as an outsider when depicting the subject of research and create power relations over their subjects. As he cautions orientalists for the narratives they produced, Said also alerts area studies, a field developed in western countries during the postwar era, as bearing a resemblance to Orientalism that takes upon themselves the privilege of speaking on behalf of their research subject. Utilizing philology, psychological analysis, and sociology, area studies scholars too, are prone to forcing their perspective as an outsider to understand other people's culture. Said's preposition is for scholars to reform their field of study and acknowledge their bias as westerners. Simultaneously, he encourages East and Arab scholars to create their own narratives and "talk back" to the colonizers. On this solution, however, Said seems skeptical. The book, after all, analyzes orientalist texts dating back to the 1700 s to today's highly esteemed schools, hinting that there is very little change and a chance for agency throughout. He also describes the abundant orientalist texts that have been produced and republished, as well as the outstanding number of scholars migrating from West to East, which comes in stark contrast to the small number of scholars migrating from East to West. Overall, the book does not offer a quick remedy to the problem nor romanticize a solution, but rather helps provide a critical framework to understand how colonial power operates via orientalist images and reveals how educational institutions serve as prongs for authoritarian control.

Said's work is not without critics. Scholars are mindful that Said may have reduced the 'East' to 'Islam' and can fall into a similar form of generalization of the East as the orientalists themselves. Critics to Said also take note that Orientalism is limited to the study of Western perspective of East, and not the perspective of the East themselves, as Tahru stipulates, "Orientalism [...] is far from being about the Orient. On the contrary, its subject is the Euro-American academy and the power/knowledge axis of that institution" (Yaeger, 2007). While the book reveals the misrepresentation of the East, it does not mention the representation that the East prefers for themselves. Said addresses this critic in his next book, Culture and Imperialism (Said, 1993), that reads through the workings of classic western literature in its depiction of the East as well as the writings by non-western writers to show their resistance. In this latter work, Said unpacks the "Orient" and "East" extensively, reaching as far as India, Australia, and the Caribbean. In Orientalism, however, Said limits his interrogation to the western authority in European land and does not address how the Orient could travel and face their colonizer through migration - issues which 
postcolonial studies scholars pursue further, using the paths established by Said.

\subsection{Cultural Identity and British Culture Studies' View of Diaspora}

The work of understanding migration and its impact on diaspora is also taken up by culture studies scholars, beginning with Stuart Hall, whose Marxist poststructuralist approach was foundational in the development of British Culture Studies (BCS) in the 1970s. Hall views culture as a construction and a field where power struggles take place. This perspective is reflected in his paper "Cultural Identity and Diaspora", where he speaks of the agency of the diaspora, aptly referring to the community as "new postcolonial subjects" (Hall, 1990).

There are two main contributions of "Cultural Identity and Diaspora" to postcolonial scholarship. First is the theorization of identity, in which Hall provides a framework to view race and other identity categories through the lens of social constructivism, which allows scholars to problematize authenticity. Identity, according to Hall, is a 'production', "which is never complete, always in process, and always constituted within, not outside, representation" (Hall, 1990). Hall's view that identity is constructed not only through how we portray ourselves but also through how others perceive us, reverberates the enunciation theory in which linguists identify the inevitable discrepancy between the subject speaking and the speech that represents the subject (see Phillips, 2006). Hall's proposal also resonates with Louis Althusser's view that an individual gains subjectivity through subjectivication by the state (Althusser, 2006). Both Hall and Althusser show importance in recognizing a person's identity not only as a matter of positioning oneself but also of how others perceive her or him. The intelligibility of oneself is only made possible through subjectification. This view reveals the impact of the power structure and nation-state on one's subjectivity.

The second contribution of Hall's article is his conceptualization of cultural identity, which derives from the notion of a 'collective selves' in which a community imagines common historical experiences and cultural values. The Pan-Africanism coalition, which DuBois prompted in the 1940 s, is an example of cultural identity in this format. This paradigm consequently believes in a stable, unchanging notion of identity, which considers a 'true' identity as rooted in the homeland. Meanwhile, as Hall underlines the importance of history as a referent in constructing the diaspora's subjectivity, he perceives history as not fixed and continues to change. He compels readers to view identity that does not require rediscovery and connection to the homeland but rather produced through the 're-telling of the past (Hall, 1990). Hall views the past as never fully attainable, and for a diaspora specifically, the homeland is not what it was. He asserts, "The original 'Africa' is no longer there" and contemplates how African diaspora discovers the past not in Africa, but the Caribbean or through the British Jamaican community, creating an amalgamation that is Afro-Caribbean identity (Hall, 1990).

Simultaneously, though bound on collectiveness, Hall's view of cultural identity does not focus on similarities, collectivity, and sameness but rather on 'ruptures and discontinuities'. As history is fractured and changing, identities become the product of the relentless attempts to recreate the "fractured rubric of the past" (Hall, 1990:225). Hall stipulates, "Identities are the names we give to the different ways we are positioned by, and position ourselves within, the narratives of the past" (Hall, 1990:225). He views cultural identity as "a process of 'becoming' as well as 'being' ... belong[ing] to the future as much as the past," (Hall, 1990:225). As such, identities are both who we are and who we continuously attempt to be. Hall's concept 
of identity formation lies in the belief that agency is plausible through cracks and paradoxes, and subjectivity is obtained through the constant mending of the fracture, located in both the past and future. The diaspora identity is rigorous yet fragile, hopeful, and skeptical, all at the same time.

Hall's conceptualization of diaspora as those who had fled western imperialism and mended trauma by excavating 'fractures and discontinuities' of the past and within the subject resonates with the work of postcolonial scholars. In Orientalism (1979), Said discusses how western imperialism does not only dictate who the colonized is, but also influences how they perceive themselves. Hall's formulation of identity follows Foucault's view on the connection between power and knowledge, in which power is exercised through knowledge, institutions that teach and disseminate knowledge, as well as the discursive practices that are taught to the people and within which they participate (Foucault, 1973; Foucault \& Gordon, 1980). As a result, those under power behave and think as subjects of power and unconsciously participate in the discursive practices that maintain the status quo. However, Hall sees hope in identity construction and views it as a possibility for the agency, such as in the ways the diaspora takes an active role in seeking reference to the homeland, creating hybrid identities, and making coalitions between communities.

In working against orientalist images, Hall sees hope in active movement and communities that work to define themselves. He begins and ends his paper with a hopeful note as he observed black Caribbean cinema on its rise. He talks about the "third world narratives" and their ability to "talk back" to the western empire by creatively reconfiguring their position as diaspora and acknowledge the heterogeneity, fractures, and differences. He writes, "The diaspora experience as I intend it here is defined, not by essence or purity, but by the recognition of a necessary heterogeneity and diversity; by a conception of 'identity; which lives with and through, not despite, difference; by hybridity" (Hall, 1990:235).

Hall's work should be read together with Homi Bhabha's work on 'hybrid culture', which he views as the outcome of cultures that collides and are in conflict with one another (Bhabha, 2004). Bhabha defines hybridity through the position of the migrant and colonized, and the experience of being not at home ('unhomely') and 'in-between'. He views the 'in-between spaces' as a space of ambivalence where the identity of the modern world is located. He views 'inbetween spaces' as areas to exercise agency and strategize. In such spaces, one can creatively create collaboration, where societies claim their identity and contest stereotypes (Bhabha, 2004:2). He also furthers Said's theories by elaborating the concepts of cultural identity and revealing the junctures that might take place between the previously clear-cut binaries of colonized/colonizer, eastern/western, civilization/culture, which Said has elaborated. While Said does not address the dynamics between each binaries nor their collision, Bhabha sees how the binaries can overlap and are in tension, creating a hybrid culture that can empower the colonized. Hall and Bhabha therefore can be viewed as pioneers in their effort to conceive 'diaspora' as a political term that allows for agency, rather than viewing the term as representation of a fragile minority group.

Hall's essay leaves room for further work on diaspora and diaspora identity. First of all, as it overwhelmingly focuses on black diaspora - stemming from Hall's observation of Jamaican Britishness connected through colonial ties -, and consequently leaves open the discussion of diaspora groups other than the black diaspora. With historical materialism as the prime approach, Hall's work illustrates a critical approach and not an immediate 
remedy to diaspora and migrants elsewhere. In other words, Hall would encourage a similar rigorous interrogation of diaspora communities in other locations.

While the essay opens the way for studies on diaspora, works on groups such as Asian diaspora in English-speaking countries and Black communities in China can follow a similar framework in understanding their own methods of agency. One can also further Hall's work to approach the case of escaped ex-slaves who moved in America beyond to Canada to seek freedom.

Hall's work allows for interrogation on the various movements of people caused by different forms of colonization and systems of power. It also leaves open the discussion to understand the new power structures that exist in the host country. Immigrants face repression in their homeland and during their entry to the host country, but the complication continues as migrant communities often are forced to low-wage work and sweatshops. Colonization may persist and intensify as diaspora's labor and their bodies are exploited in their host country. In extension to this, we can investigate the systemic repression experienced by coolies and low-waged migrants in the host country and how it affects the ways in which they construct cultural identity in such a highly repressive space. This work is among others undertaken by ethnic studies and critical refugee scholars. Additionally, theorists discussed so far in this article have not addressed mobilization caused by work migration and if voluntary movement across borders for the pursue of livelihood and capital can be considered under this frame of thinking. The rest of this essay will address modern migration by specifically reflecting on the position and experience of the Asian diaspora.

\subsection{Asian Diaspora and Hybridity}

Western scholars propelled the term 'diaspora' to identify the communities who are forced to relocate due to colonization, often used to describe the movement of migrants from the eastern hemisphere to the west. The world then witnessed conflicts in which the Orient served a more complex role in imperialism and geopolitics, such as the Japanese colonization in World War 2 and the proxy wars in Korea and Vietnam brought by Cold War. Such events help challenge the west's simplified view of Asia or the so-called East. At the same time, a critical view on migration also requires a critical understanding on imperialism by the west that instigated global conflicts, and this brings a more complex view on waves of migration and refugees in today's context. Simultaneously, alongside the waves of refugees is the wave of skilled migrants, which bring the term 'diaspora' at a crossroads, waiting to either be entirely abandoned or reify to address today's dynamics. In this respect, Asian postcolonial scholars have spearheaded the field in reconfiguring 'diaspora' to the Asian context.

Asian cultural studies scholar Ien Ang reifies the term 'diaspora' in her article, "Together-in-Difference: Beyond Diaspora, Into Hybridity" (Ang, 2003). Ang redefines 'diaspora' and 'hybridity' using the Asian migrant perspective and discusses the various ways in which scholars have come to redefine 'diaspora' from a term which explains the exodus and displacement of victims of national hegemony and western imperialism, referring to Armenian and Jewish refugees, to a term that describes people living away from their home country. She firstly describes the irony of diaspora as an unbound community who transgresses boundaries, yet exists through exclusion and categories that put them at arm's length from others. She asserts, "The limits of diaspora lie precisely in its own assumes boundedness, its inevitable tendency to stress its internal coherence and unity, logically set apart from "others" (Ang, 2003:142). Chinese diaspora, who reside in many parts of the world, rely on the boundedness of diaspora. They pivot upon 
the term 'Chinese diaspora' in order to claim their position. This shows the workings of diaspora identity as a form of identity politics that relies on division as much as it does on coalition.

Ang views the diasporic identity as a double-edged sword, "[I]t can be the site of both support and oppression, emancipation and confinement, solidarity and division" (Ang, 2003:142). Dualities of the experiences of the diaspora are also found in the host country's treatment towards them, which many ethnic studies scholars have continued to unravel. Lisa Lowe, for instance, views how the citizenship system positions Asian Americans as the "foreigner within", a community who is included in the American economic system and exploited for their skills and labor, yet is continued to be alienated from the American culture and considered as a "perpetual immigrant" that is never truly welcomed (Lowe, 1996).

Ang rejects the over-celebration of diaspora as untethered nationalism, free from containment of the nation-state. She views diaspora's nationalism as a form of 'imagined communities, a term coined by Benedict Anderson to explain nationalism as that which is imagined, practiced by citizens that are geographically apart and created through a sense of connection that only exists in the imagination (Anderson, 2006). Ang uses the term 'proto-nationalist to explain how the diaspora community's senses of nationalism and transnationalism are established through imagination, and the diaspora identity is not as porous as many assumed. Instead, diaspora identity struggles by continuously needing to demarcate and close itself from other identities in order to establish itself. She opines, "The politics of diaspora is exclusionary as much as it is inclusionary, just like that of the nation" (Ang, 2003:144). This reveals how the politics of diaspora mimics the system of exclusion and inclusion as practiced by the nationstate, and this challenges the assumption that diaspora is uncontained, free-flow, and can freely assert agency and transgresses state power. Ang, therefore, sees problems in the rigidity of the conventional notion of 'diaspora'. She encourages readers to think of migrants and communities outside of their homeland "beyond diaspora" or beyond the conventional notion of diaspora as settled and finite, prompting the paper's title: 'beyond diaspora, into hybridity'.

In the second half of her paper, Ang engages with the concept 'hybridity' to explain the position of diaspora communities. Stuart Hall and Homi Bhabha introduce 'hybridity' as a political mechanism to interrogate and 'talk back' to the British Empire (Bhabha, 2004). Hall's example of hybridity is the "Black British", a pan-African black identity used to fight against the empire. Though black Britishness aims to counter the white power structure, Hall notes, it is a hybrid between white and black, and Africa and Britain (Hall, 1990). Meanwhile, Bhabha's idea of hybridity is articulated through 'mimicry', a concept which explains how the colonized 'mimics' the white colonizer, yet practicing it slightly differently to mock the white colonizer's culture. He writes:

"... colonial mimicry is the desire for a reformed, recognizable Other, as a subject of a difference that is almost the same, but not quite. Which is to say, that the discourse of mimicry is constructed around an ambivalence; in order to be effective, mimicry must continually produce its slippage, its excess, its difference. The authority of that mode of colonial discourse that I called mimicry is therefore stricken by an intermediacy: mimicry emerges as the representation of a difference that is itself a process of disavowal" (Bhabha, 2004:122).

Through mimicry, the colonized creates a hybrid culture that taunts and resists the colonial authority by resembling the colonizer's culture "but not quite". The practice of mimicking those of power aims to 
displace the gaze and disturb the normalized colonial idea of the subject. Aware that mimicry could be perceived as a defeat of the colonized, Bhabha purposes to embrace this perceived sense of defeat while viewing it as a chance to seek power and play around with the colonizer's culture. The mimicry aims to disturb discourses as it serves as both a "resemblance and menace" (Bhabha, 2004:123).

Unlike Hall and Bhabha, Ang takes a more nuanced view of hybridity by acknowledging the blurred boundaries between cultures, borders, and identities. She sees how intersections of borders and cultures create rich cultural fusion and communities that are amalgamations of cultures and intersections of peoples and communities. However, Ang resists viewing hybridity as effortless action as she notes several challenges. First, she looks into the continuous resistance to the intermixing of cultures and describes the white cultures' fear of being dominated by the cultures of its immigrants, as illustrated by the notion of 'Asianizing' Australia, or 'multi-ethnic' Britain (see Parekh \& Runnymede Trust. Commission on the Future of Multi-Ethnic, 2000). Secondly, she explains that the route of identity construction as one which does not only involve the host country and homeland, but other signifiers and ethnic markers. For instance, Ang discusses the complicated case of the Chinese diasporic identity as a category that is not based on origins homeland. While Chinese-descent Indonesians and Chinese migrants from Hong Kong, Taiwan, or Vietnam are included within this category, they have unconnected histories, they speak different languages, and might not feel connected to one another. This poses a challenge to the pan-Asiatic diaspora identity. Her paper, therefore, expresses skepticism to the overt celebration of the hybrid culture of the diaspora community because of the impossibility of having a problem-free diaspora category, and the Asian context helps reveal this.
As a result, Ang engages with hybridity differently from Hall and Bhabha by seeing hybridity not as a solution, but rather as a frame of thinking that provides us with a critical framework to resist essentialism and provide caution when approaching blurred lines of differences. She speaks of hybridity as a "heuristic device in analyzing complicated entanglements" (Ang, 2003:150) that works against the essentialist and divisiveness of ethnic and diaspora identity, and this is poignantly illustrated by the case of Chinese diaspora, which creates the division between Chinese, non-Chinese, and "not Chinese enough". Though diaspora community works to create an alliance and advocate for ethnic minorities living in host countries that alienate them, Ang is cautious of what the diaspora identity may exclude. Hybridization, therefore, works to blur these divisions and serve to include rather than divide people.

Following Ang's path, postcolonial studies and cultural studies scholars in Southeast Asia have sought to uncover hybrid Asian diaspora, their intricate ideas of home, and their liminality. Melani Budianta explains the tender position of Filipino Indonesian family residing in Singapore using the phrase 'precarious cosmopolitanism' (Budianta, 2016), while Carol Chan looks into how Indonesian domestic worker's migration to East Asia leads to the reconfiguration of ideas of freedom as well as gendered and moral practices (Chan, 2017). Taking on cultural studies view of political agency, scholars also look into diaspora literature as "narratives as longings" that reifies ideas of homeland (Gabriel, 2011) and tackle new patterns of repression as a reaction to global migration, such as backlash in the form of nativism and heighten tension between nationalism and globalization (Kim, 2017). These works explain the various tensions and structures of power that exist in the Asian region, be it from homeland, host country, and recognize the regional political-economical systems of 
control that oversee their movement across borders. This shows how the case of InterAsia mobility has resulted into substantial contribution to postcolonial studies by giving input on what hybridity and agency look like to a diaspora in the globalizing Asia.

Ang's views as an Asian cultural studies scholar help highlight that for the Asian context, the term 'diaspora' remains relevant and useful, particularly to understand 'cultural identity' in a highly globalized world. Ang uncovers this further in her work, On Not Speaking Chinese: Living Between Asia and the West (Ang, 2001), reflecting on her own experience as an Indonesian-born Chinese, living between Netherlands and Australia. For Ang, as for many Asians (migrants or non-migrants), the tension between the West and Asia still persists, and is made more apparent in this contemporary global world. Furthermore, Ang hints at the role of reflective work by scholars who are diasporas themselves and that their position allows them to strategically analyze the "complicate entanglement [of the globalized world] because it is embodied in her own life trajectory" (Ang, 2003:3). Intellectuals and scholars too, have become a significant part of the skilled workers who travel and move beyond borders, and their critical view as subjects of geopolitical and institutionalized power should not be overlooked.

\section{4. 'Global Diaspora': A Crossroad for Multiple Fields}

So far, this paper has engaged with the tenets in postcolonialism and understanding the complicated position of the Asian diaspora and the ethnic Chinese that help unsettles and challenge concepts in the field. In this part of the article, I will discuss how postcolonialism continues to contest and challenge the term diaspora. By doing so, the article will also view the intersection between postcolonialism and other fields in humanities, which view the position of the global diaspora as locus.

This article begins with the book Global Diaspora (Cohen, 2008), where Cohen dissects the term 'diaspora'. In his book,
Cohen also expresses his concern on how society has come to use the term in an oversimplified manner, prompting him to reify diaspora and elaborate on its complexity. Originally used to explain the British and European colonizers who arrived in the foreign land during the mercantile and colonial era, the term 'diaspora' has also been used to explain the victims of colonization who had to leave their homes and a form of identity politics used to 'talk back' to the western empire. However, different from postcolonial and cultural studies scholars discussed in this article, Cohen expresses skepticism on the postmodern idea of 'hybridity'. He critiques postmodern scholars for their simplified view of a pan-African identity and cultural hybridity of the Caribbean migrants, and he suggests that historical complexities of the Caribbean community has been overlooked, as those who arrived in America, France, Netherlands, and U.K. each faced different social structure and power dynamics. He writes, "[W]hatever the sophistication and complexity of the black Atlantic argument at root it is a historical simplification, which cannot fully explain the process of indigenization and creolization in the Caribbean, despite the lack of indigenes" (Cohen, 2008:153). Cohen contests the view of hybridity as a formulaic concept for culture interactions, and seek to better understand the amalgamation of cultures as a complex phenomenon, in which the indigenous culture and the culture coming from outside of the geography have become undiscerned. His statement also reveals a critic toward postcolonial scholarship that is Euro-centric, which overlooks the experience of the Caribbean diaspora in Asia.

The different perspective that Cohen proposes compared to other scholars mentioned in this writing is mostly apparent in his seventh chapter, "Diaspora in the Age of Globalization", where he discusses migrants who relocate due to the global economy. Cohen views this group of diaspora as the ones who mostly benefit from migration, and globalization is a moment that 
"enhanced the practical, economic and affective roles of diaspora", providing them with the various modes to adapt to the situations they face and gain power by integrating with the cosmopolitan society (Cohen, 2008:176). Cohen is also optimistic that the disparities between one diaspora community to another, and between the middle-upper class and the low-paid laborers to which diaspora and migrants are often divided as they arrived in the host country, can be solved as the diaspora community has become more mixed in its profile. He sees possibility in collective change, stating, "with many being educated and professionally qualified and others able to engage in collective capitalism, has allowed them to avoid the worst impact of global restructuring" (Cohen, 2008:176). As Cohen traced the progression on how the term 'diaspora' has traveled from the dark ages of western imperialism, to the voluntary migrations of third world professionals to cosmopolitan cities, he seems hopeful that the fate of diasporas can change under globalization.

Unfortunately, in this work, Cohen does not problematize capitalism nor reveal its pervasiveness in all aspects of life, making it equally, if not more dangerous, than colonialism. Consequently, scholars have since paid closer attention to the material reality of the life of a diaspora, and the neoliberalist control over the community. Postcolonial scholars have questioned globalization's promise as a homogenizing force that brings prosperity and access to all as it instead has caused the workers' precarity, the rise of sweatshops, low-paying jobs for women in the Global South, and unequal flow of goods and capital, which further elucidates the role and limits of nations and peoples of the Global South, as set by the capitalist system (Budianta, 2016; Grewal, 2005). Postcolonial scholars have revealed how global capitalism serves as another power structure that mimics western imperialism, making way for a classconscious approach and research on migration and migrant communities. Ethnic studies scholars reveal the pressure posed upon refugees to take part in U.S. capitalism to pay back the "debt" for the freedom that has been "bestowed" upon them (Nguyen, 2012). Nation-states implement resettlement systems that encourage refugees to become productive, independent workers and entrepreneurs as soon as they set foot in the host country, all while they struggle to reconcile familial and cultural values from homeland and face the pressure to survive and work in the host country (Ong, 2003). This has swiftly led to the development of Global South studies, which discusses how the end of colonialism and World War 2 has made way for new power structures over Asian and African countries (Prashad, 2012). Here, we observe the interconnection between postcolonial scholarships with other fields such as political economy, Ethnic studies, and Global South studies.

\section{Conclusion}

Postcolonialism began as a critical approach that dissects power structures through which western imperialism operates, and now the field has grown to a study of the globalized world and its repression towards the subaltern. As a field of study, postcolonialism remains significant as it scrutinizes structures of power in the modern era as those that replicate imperialist strategies that are capital-driven, and we see this in the field's engagement with the term 'diaspora'. The word 'diaspora' remains to be contested between scholars who are cautious that the broadening of the term might drive attention away from the plight of communities displaced by western colonization, with those who wish to speak more broadly about the experiences of moving across borders, the struggle of seeking space and facing nation-state's control.

This paper's epistemological examination of the term 'diaspora' signifies several shifts. First is the shift in the operational use of the term, from that which infers permanent migration, war refugee, migrants impacted by western colonization in Asia, Africa, 
Near, and Far East, taking away indigenous land in the American continent and Australia, to a term which also explains temporary migration and economic migration caused by globalization. The latter allows us to see western capitalism's encroachment to the Global South that instigates the flow of workers beyond borders. The term "diaspora" expands from a western academic jargon of anti-colonialism that reveals the systems of power that marginalize migrants, refugees, to a term expanded by scholars of Asia to describe migrants from all corners of the world whose identities are layered, and whose movement is instigated by western colonialism and western capitalism. The latter view of diaspora allows the term to make space, invite coalition, and create conclaves to speak against structures of power that marginalize and position them as precariat.

Secondly, the epistemological examination of the term 'diaspora' reveals how power operates to displace humans and control their mobility. Previously, war violence and colonization were culprits. Today, the encroachment of neoliberalism to the Global South, the lure of globalization, and the promise of economic prosperity abroad are pushing communities to seek work elsewhere. Indeed, colonization too, has always been economically motivated. However, today we see a more mutable form of hegemony in neoliberalism as it operates through languages of freedom (De Lissovoy, 2015). Participation in a capitalist system is communicated through the lure of the freedom to trade, consume, and work, and, for many, it encourages the freedom to travel and migrate. Consequently, scholars of the Global South are working to uncover the marginality of migrant domestic workers, international students, workers living between borders, and contractual migrant workers with limited work permits, which encourages postcolonial studies to revisit the term 'diaspora'. Their aim is to bring forth the lived experiences of migrants of the Global South whose precarity, multiple identities, and temporary migration often make them illegible to the conventional notion of 'diaspora' and studies of migration. The migrants themselves have a say in using the term 'diaspora', as exemplified by the Indonesian Diaspora Network who adopts the academic jargon to organize and bring national awareness to their plight. The redefinition of the term 'diaspora' by scholars and people of countries formerly colonized by western nations is also an act of decolonizing the knowledge previously dictated by the 'West'. In this decolonization, the lived experience of each migrant community becomes a locus to define themselves and reveal the hegemonic structure that represses them as global migrants.

Third, the expansion of the term 'diaspora' indicates the influence of postmodern thinking in viewing the human subject. This approach does not trace a migrant's origin back to the homeland, rather it problematizes the idea of 'origin' itself. Individuals are viewed as layers upon layers, transgressing physical and emotional borders, full of contradictions and fractures. Their identity is discovered and expressed through these fractures as well as through new spatial and emotional referents. This postmodernist approach bears the characteristics of a scientific paradigm (Kuhn \& Hacking, 2012) by competing against the essentialist's view of the 'self' and 'borders', while simultaneously opening new paths to interrogate these terms. Under this view, a sense of being at home, for instance, can be sought beyond referencing the homeland and host country, and instead explored through imagined spaces that are creatively created as Hall has illustrated in his essay. Through this framework, a person's ethnicity is no longer expressed by hyphens that combines two spaces, such as Asian-American or ChineseMalay, but rather discovered through multiples spaces and referents as exemplified by solidarity among Chinese-descents that transgresses national identity, or between black people, regardless of origins and nationalities. As Ang reveals, however, the postmodernist view of diaspora identities 
does not fully eliminate the mechanism of self and borders. Instead, notions of borders and boundaries operate in some ways still, as a diaspora community may establish themselves through exclusion as much as they do through inclusion.

Ideas of borders are also continuously blurred, and the dichotomy of home country/host country, as well as colonized/colonizer to which postcolonialism has pivoted upon, can no longer contain the dynamic of transnational migration. In the recent decade, the need to speak broadly about the many experiences of migrants coincides with the rise of antiglobalization movements in the form of ultraright-wing groups who reject migrants and refugees, recently indicated by the U.K.'s stance to leave the European Union and the U.S. government's policy to heighten border control. These movements and policies are reactionaries to the postmodern thought that celebrates hybridity and the blurred boundaries between nation-states. To this context, the questions of "Who qualifies as a migrant?", "What is a diaspora?", and consequently, "How can the state better protect a diaspora?" become increasingly urgent.

\section{References}

Althusser, L. (2006). Ideology and ideological state apparatuses (notes towards an investigation). The anthropology of the state: A reader, 9(1), 86-98.

Anderson, B. R. O. G. (2006). Imagined communities: reflections on the origin and spread of nationalism (Vol. Rev.). New York;London;: Verso.

Ang, I. (2001). On not speaking Chinese: living between Asia and the West. New York;London;: Routledge.

Ang, I. (2003). Together-in-difference: beyond diaspora, into hybridity. Asian Studies Review, 27(2), 141154.

doi:10.1080/10357820308713372
Ashcroft, B., Griffiths, G., \& Tiffin, H. (2002). The Empire Writes Back: Theory and Practice in Post-Colonial Literatures: Routledge.

Bhabha, H. K. (2004). The location of culture. New York;London;: Routledge.

Budianta, M. (2015). Precarious cosmopolitanism: Work migration and cultural belonging in a globalized Asia. International Journal of Cultural Studies, 19(3), 271-286. doi:10.1177/1367877915573764

Budianta, M. (2016). Precarious cosmopolitanism: Work migration and cultural belonging in a globalized Asia. International Journal of Cultural Studies, 19(3), 271-286.

Chan, C. (2017). "Freedom is Elsewhere": Circulating Affect and Aversion for Asian and Islamic Others in Indonesia. In C.-m. Wang \& D. P. Goh (Eds.), Precarious Belongings: Affect and Nationalism in Asia (pp. 117-135). London: Rowman \& Littlefield.

Cohen, R. (2008). Global diasporas: An introduction: Routledge.

De Lissovoy, N. (2015). Neoliberalism and the contradictions of freedom: Ideology, subjectivity, and critical pedagogy. Texas Education Review, Volume 3(Issue 2), 44-54.

Dodson, J. (2016). Record high global migration may give new meaning to 'diaspora'. The Conversation. Retrieved from theconversation.com website:

https://theconversation.com/record-

high-global-migration-may-givenew-meaning-to-diaspora-59365

Foucault, M. (1973). Madness and civilization : a history of insanity in the Age of Reason / Michel Foucault ; translated from the French by Richard Howard. New York: Vintage Books.

Foucault, M., \& Gordon, C. (1980). Power/knowledge : selected interviews and other writings, 1972- 
1977 / Michel Foucault; edited by Colin Gordon ; translated by Colin Gordon [and others] (1st American ed. ed.). New York: Pantheon Books. Gabriel, S. P. (2011). 'It ain't where you're from, it's where you're born': retheorizing diaspora and homeland in postcolonial Malaysia. Inter-Asia Cultural Studies, 12(3), 341-357. doi:10.1080/14649373.2011.578791

Gabriel, S. P. (2015). "Local" and "national" transformations: Cultural globalization, heterogeneity, and Malaysian literature in English. The Journal of Commonwealth Literature, $\quad 51(1), \quad$ 145-164. doi:10.1177/0021989414566517

Gouda, F. (1993). The Gendered Rhetoric of Colonialism and Anti-Colonialism in Twentieth-Century Indonesia. Indonesia(55), $1-22$. doi: $10.2307 / 3351084$

Grewal, I. (2005). Transnational America: feminisms, diasporas, neoliberalisms. Durham, N.C;Chesham: Duke University Press.

Hall, S. (1990). Cultural identity and diaspora : Identity: community, culture, difference: Lawrence and Wishart.

Hall, S. (2002). When Was the 'PostColonial'? Thinking at the Limit. In I. Chambers, Lidia Curti (Ed.), The Postcolonial Question (pp. 242-260): Taylor and Francis.

Kim, H. M. (2017). Let's Save the Nation from Being Anti-Multicultural! Precarious Belongings: Affect and Nationalism in Asia, 137.

Kitamura, Y. (2017). Long way home: The life history of Chinese-Indonesian migrants in the Netherlands. Wacana, 18(1), 24-37. doi:https://doi.org/10.17510/wacana. v18i1.572

Kuhn, T. S., \& Hacking, I. (2012). The structure of scientific revolutions / Thomas S. Kuhn ; with an introductory essay by Ian Hacking
(Fourth edition. ed.). Chicago ;: The University of Chicago Press.

Latifa, I., \& Beta, A. R. (2019). Citizenship as Experience: The Lives and Labours of Overseas Indonesian Scholars. International Review of Humanities Studies, 4(1). doi:https://doi.org/10.7454/irhs.v4i1. $\underline{109}$

Lowe, L. (1996). Immigrant acts: on Asian American cultural politics. Durham: Duke University Press.

Murray, L., Jean-Baptiste Meyer. (2014). Diaspora Encyclopedia Britannica.

Nguyen, M. T. (2012). The gift of freedom: war, debt, and other refugee passages. Durham: Duke University Press.

Ong, A. (1999). Flexible citizenship: the cultural logics of transnationality. Durham: Duke University Press.

Ong, A. (2003). Buddha is hiding: refugees, citizenship, the new America (Vol. 5). Berkeley: University of California Press.

Parekh, B., \& Runnymede Trust. Commission on the Future of MultiEthnic, B. (2000). The future of multiethnic Britain. London: Profile Books.

Parreñas, R. S., \& Siu, L. C. D. (2007). Asian diasporas: new formations, new conceptions. Stanford, Calif: Stanford University Press.

Phillips, J. (2006). Who is the Subject of Enunciation? Retrieved from https://courses.nus.edu.sg/course/ellj wp/enunciation.htm

Prashad, V. (2012). The Poorer Nations: A Possible History of the Global South. London: Verso.

Said, E. W. (1979). Orientalism (Vol. 1st Vintage Books). New York: Vintage Books.

Said, E. W. (1993). Culture and imperialism (1st ed.). New York: Knopf.

Vickers, A. (2005). A history of modern Indonesia. Cambridge, UK; New York;: Cambridge University Press. 
Widjanarko, P. (2007). Homeland, identity and media: A study of Indonesian transnational Muslims in New York City. (3272909 Ph.D.), Ohio University, Ann Arbor. Retrieved from

https://search.proquest.com/dissertati ons-theses/homeland-identity-mediastudyindonesian/docview/304821893/se2? accountid=17242 ProQuest Dissertations \& Theses Global database.
Yaeger, P. (2007). Editor's Column: The End of Postcolonial Theory? A Roundtable with Sunil Agnani, Fernando Coronil, Gaurav Desai, Mamadou Diouf, Simon Gikandi, Susie Tharu, and Jennifer Wenzel. PMLA/Publications of the Modern Language Association of America, 122(3), 633-651. doi:10.1632/pmla.2007.122.3.633 